\title{
PERSPEKTIF TERPADU: ALTERNATIF TERBAIK ATAS KONSELING KONVENSIONAL
}

\author{
Wening Cahyawulan ${ }^{1}$ \\ Arga Satrio Prabowo ${ }^{2}$
}

\begin{abstract}
Abstrak
Berbagai teori konseling yang ada saat ini bukanlah tanpa keterbatasan. Kompleksitas masalah yang dialami oleh seorang individu, terkadang membuat sebuah teori pendekatan konseling tidak mampu berdiri sendiri dalam menangani masalah dan dibutuhkan perspektif pendekatan lain atau teknik konseling lainnya. Beberapa individu memiliki masalah yang cukup kompleks sehingga perspektif pendekatan satu dengan pendekatan lainnya harus diguanakan agar dapat menangani masalah individu secara tuntas. Hal ini terjadi karena teori pendekatan konseling tidak dapat menangani semua masalah yang terdapat pada diri individu. Atas dasar fakta tersebut, maka lahirlah sebuah perspektif atau pendekatan konseling yang dapat menggabungkan beberapa teori pendekatan atau teknik-teknik tertentu dalam berbagai pendekatan konseling yang memungkinkan menyelesaikan berbagai permasalahan yang dialami oleh individu. Perspektif atau pendekatan tersebut dikenal dengan sebutan perspektif integratif atau perspektif terpadu. Tulisan ini akan membahas efektifitas dari perspektif integratif dalam menangani berbagai kasus dalam proses konseling.
\end{abstract}

Kata Kunci: Konseling, Perspektif Terpadu

\section{PENDAHULUAN}

Konseling denganpendekatanterpadu merupakan konseling yang mempelajari dari berbagai pendekatan yang mungkin akan membantu memahami dan bekerja dengan individu dengan masalah mereka (Arkowitz dalam Arkowit; 2002). Keterbatasan teoriteori konseling yang ada saat ini salah satunya adalah tidak mampu menangani berbagai macam permasalahan. Permasalahan yang dapat ditangani memerlukan kriteria-kriteria tertentu, sehingga menjadi sangat tidak fleksibel. Berangkat dari permasalahan tersebut, lahirlah prespektif konseling terpadu yang menjanjikan sebuah efektifitas untuk menangani berbagai permasalahan (Corey, 2013). Konseling terpadu adalah sintesis dari berbagai pendekatan yang berbeda, dimana dimaksudkan untuk mengatasi keterbatasan teori tunggal dengan tujuan meningkatkan pemahaman dan perubahan dalam proses terapeutik dan meningkatkan efektivitas konseling (Lampropoulos \& Dixon, 2007).

Perspektif terpadu dalam psikoterapi terdiri dari eklektisisme teknis, terpadu teoritis, pendekatan faktor umum, dan terpadu asimilatif. Eklektisisme teknis fokus pada pemilihan teknik terbaik untuk konseli dan masalahnya. Fokus pada perbedaan, memilih dari berbagai pendekatan, dan teknik-teknik, terpadu teoritis perpaduan konsep dan teori diharapkan akan menghasilkan keluaran yang lebih kaya dibanding satu teori, pendekatan faktor umum mencari elemen-elemen umum antar perbedaan sistem teoritis, dan

\footnotetext{
${ }^{1}$ Mahasiswa Program Studi Magister Bimbingan dan Konseling FIP UNJ, wening.cahyawulan@gmail. com

${ }^{2}$ Mahasiswa Program Studi Magister Bimbingan dan Konseling FIP UNJ, argasatrio@gmail.com
} 
terpadu asimilatif menggabungkan beberapa intervensi dari berbagai pendekatan terapetik, tetapi tetap mendasar pada satu sistem teoritis yang koheren.

Konseling terpadu merupakan perpaduan yang tepat untuk tiga dimensi pengalaman manusia, sehingga konseling menggunakan perspektif terpadu dianggap efektif dalam membantu konseli mengatasi permasalahan yang membutuhkan berbagai pandangan. Konseling konvensional yang dianggap kaku menjadi jawaban atas ketidaksesuaian pendekatan konseling konvensional dengan budaya-budaya tertentu.

\section{KONSELING TERPADU} MENGINTEGRASIKAN TIGA DIMENSI PENGALAMAN MANUSIA

Berbagai teori konseling yang ada pada umumnya tidak berfokus pada tiga dimensi pengalaman manusia. Sebagian teori konseling berfokus pada area tingkah laku, sebagian lagi berfokus pada area kognitif, dan sebagian lagi berfokus pada area perasaan atau afektif. Konseling terpadu mengintegrasikan ketiga area tersebut ke dalam sebuah proses konseling (Corey, 2013). Konseling terpadu mempertemukan aspek-aspek afektif, kognitif, perilaku, dan sistem fisiologis dalam diri seseorang, dengan kesadaran akan aspek-aspek sosial dan transpersonal dari sistem disekeliling orang tersebut. Konsep-konsep ini dimanfaatkan dalam perspektif pembangunan manusia di mana setiap fase kehidupan menyajikan tugas perkembangan yang meningkat, perlu kepekaan, krisis, dan kesempatan untuk belajar hal-hal baru (IIP, 2014). Kenny (2006) menggunakan pendekatan client-centered, behavioral, cognitive-behavioral, dan psychopharmacological untuk membantu mengatasi depresi pada wanita AmerikaIndian. Dalam penelitian tersebut konselor berfokus pada aspek afektif, kognitif, dan perilaku pada konseli untuk menurunkan depresi dan ketergantungan konseli terhadap alkohol. Peneliti menggunakan pendekatan client-centered untuk membuka perasaan dan permasalahan konseli, selanjutnya peneliti menggunakan pendekatan cognitivebehavioral dalam mengatasi depresi atas kehamilan putri remajanya. Latar belakang budaya Amerika-Indian berpengaruh atas sikap tidak asertif konseli, maka peneliti menggunakan pendekatan behavioral dalam mengatasi hal tersebut. Konseling dengan psychopharmacological dilakukan dalam menangani kecanduan konseli atas alkohol. Berdasarkan deskripsi di atas, pendekatan terpadu ini membantu konselor dalam menghadirkan ketiga dimensi pengalaman tersebut dalam proses konseling.

\section{KONSELING TERPADU EFEKTIF DALAM MENANGANI KASUS}

Nocross dan Wampold (dalam Corey, 2013) mengungkapkan bahwa efektifitas dalam sebuah praktik konseling membutuhkan fleksibilitas dan prespektif terpadu. Prespektif konseling terpadu memandang bahwa konseling atau psikoterapi harus dapat disesuaikan dengan kebutuhan dan konteks konseli, sehingga konseling terpadu memberikan fleksibilitas bagi konselor untuk mengintegrasikan berbagai pendekatan dalam sebuah proses konseling. Sebuah meta-analisis yang dilakukan oleh Smith dan Glass (1977) berhasil membuktikan bahwa konseling terpadu memiliki efektifitas yang tinggi dalam menangani berbagai masalah. Dalam penelitian tersebut Smith dan Glass meneliti 475 studi (dengan berbagai permasalahan) dan membandingkan antara yang ditangani dengan konseling terpadu dan yang tidak ditangani menggunakan konseling terpadu. Hasil penelitian tersebut menyebutkan bahwa konseli yang ditangani masalahnya dengan pendekatan konseling terpadu memiliki kondisi akhir rata-rata $75 \%$ lebih baik dari pada yang tidak ditangani dengan konseling terpadu (Smith \& Glass, 1977). Meta-analisis di atas membuktikan bahwa fleksibilitas yang diberikan oleh pendekatan konseling terpadu terbukti efektif dalam menangani berbagai permasalahan, sehingga konselor dapat memanfaatkan konseling terpadu untuk 
menangani konseli.

Penelitian lainnya dilakuka oleh Kenny dalam membantu konseli wanita Amerika-Indian berusia 37 tahun mengatasi permasalahan depresi (Kenny, 2006). Kenny menggunakan pendekatan client-centered, behavioral, cognitive-behavioral, dan psychopharmacological.Padaawalkonseling, klien sangat tertutup kepada konselor. Oleh sebab itu, Kenny menggunakan penguatan minimal dan mendengarkan reflektif yang merupakan bagian dari pendekatan client-centered untuk membuka perasaan dan permasalahan konseli. Selanjutnya, berdasarkan permasalahan konseli atas depresinya, Kenny menggunakan pendekatan cognitive-behavioral dalam mengatasi depresi atas kehamilan putri remajanya. Latar belakang budaya Amerika-Indian berpengaruh atas sikap tidak asertif konseli, maka Kenny menggunakan latihan asertif yang merupakan pendekatan behavioral dalam mengatasi permasalahannya. Konseling dengan psychopharmacological dilakukan dalam menangani kecanduan konseli atas alkohol. Berdasarkan hasil konseling, maka Kenny melakukan follow up setelah satu tahun pelaksanaan konseling. Hasil follow up menunjukkan pengaruh positif terhadap pelaksanaan konseling terpadu Kenny terhadap konseli.

Penelitian lainnya dilakukan oleh Rijn dan Wild yang melakukan konseling terpadu dalam menangani masalah kecemasan dan depresi komunitas (Rijn \& Wild, 2013). Rijn dan Wild memadukan pendekatan analisis transaksional, gestalt, dan person-centered. Hasil penelitian menunjukkan bahwa konseling terpadu efektif untuk mengatasi kecemasan dan depresi pada komunitas.

Hasil penelitian yang menunjukkan efektivitas konseling terpadu dilakukan oleh Bethke, dkk., dalam menangani kasus anak dengan ADHD (Portrie-Bethke, Hill, \& Bethke, 2009). Konseling dilakukan dengan memadukan adlerian play therapy dan Adventure-Based Counseling (ABC) yang menghasilkan penelitian konseling terpadu memberikan kontribusi yang sukses dalam strategi coping anak dengan ADHD. Melalui berbagai hasil penelitian tersebut, maka konseling terpadu terbukti efektif menangani berbagai permasalahan dalam konseling. Konseling terpadu menjadi jawaban atas kekakuan berbagai pendekatan yang tidak mampu mengatasi permasalahan kompleks yang

\section{PENDEKATAN TERPADU MENJADI JAWABAN TERHADAP KETIDAKSESUAIAN BUDAYA}

Konselor sebagai profesional hendaknya mampu mempertimbangkan berbagai latar belakang budaya konseli. Hal tersebut dikarenakan konselor tidak akan dapat memahami individu seutuhnya jika mengabaikan identitas konseli, seperti gender, ras, budaya, orientasi seksual, sosialekonomi, dan agama (Sue \& Sue, 2008).

Pada penanganan kasus konseling, seringkali konselor merasa tarpaku atas satu pendekatan konseling tertentu. Padahal, filosofi suatu pendekatan konseling terkadang tidak sesuai atas nilai-nilai budaya tertentu. Contohnya dalam pendekatan analisis transaksional yang berkembang di Amerika, memungkinkan pola komunikasi egaliter antar individu berbentuk ego state dewasa $\leftarrow \rightarrow$ ego state dewasa. Sementara itu, budaya di Indonesia menekankan cara berkomunikasi yang berbeda antara individu yang lebih tua dan lebih muda sehingga sulit terjadi komunikasi egaliter antar individu.

Melalui konseling terpadu, konselor dapat mengukur kebutuhan-kebutuhan khusus yang dibutuhkan oleh konseli berdasarkan latar belakang etnis dan budaya yang dibawanya ke dalam proses konseling. Konselor dihadapkan pada situasi dimana konselor harus mengembangkan fleksibilitas dalam menentukan arah strategi dalam konseling (Corey, 2013). LaFromboise mengungkapkan dalam penelitiannya kepada konselidengan tradisiAmerika-Indian, ia tidak dapat menggunakan pendekatan konseling konvensional karena adanya sensitivitas nilai budaya Amerika-Indian (LaFromboise, 1990). Menurut LaFromboise, konseling 
konvensional yang dikembangkan oleh non Indian, dianggap rasis oleh etnis Indian. Oleh sebab itu, LaFromboise menggunakan pendekatan terpadu dalam membantu konseli menangani permasalahannya. Konseling dilakukan dengan memadukan pendekatan person-centered, rogerian social learing, dan behavioral. Hasil penelitian menunjukkan bahwa konseling terpadu memberikan efek positif terhadap konseli Amerika-Indian. Oleh sebab itu, konseling menggunakan prespektif terpadu membantu konselor bekerja dengan latar belakang sosial, budaya, spiritual, dan politik yang dimiliki oleh konseli, sehingga proses konseling tidak menjadi sebuah proses yang menekan dan membuat konseli merasa tidak nyaman.

\section{KESIMPULAN}

Berangkat dari kekurangan yang dimiliki berbagai pendekatan konseling yang telah ada, konseling terpadu memberikan sebuah jawaban dari permasalahan yang ada. Prespektif konseling terpadu mengijinkan seorang konselor untuk mengintegrasikan berbagai pendekatan yang dapat dimanfaatkan untuk menangani berbagai macam permasalahan yang dialami oleh konseli. Konseling terpadu memberikan fleksibilitas dalam sebuah proses konseling, dimana konselor dapat menggunakan berbagai macam pendekatan atau teknik konseling yang sesuai dengan masalah yang dialami konseli. Pemilihan pendekatan atau teknik konseling yang dilakukan konselor harus mempertimbangkan tiga dimensi pengalaman manusia yaitu kognitif, afektif dan prilaku. Ketiga dimensi tersebut penting untuk diintegrasikan dalam sebuah proses konseling agar konseli mendapatkan pengalaman yang mendalam. Manfaat lainnya yang dapat diperoleh dari pendekatan ini adalah efektif dalam menangani berbagai macam kasus atau permasalahan. Pada beberapa penelitian yang telah dilakukan, konseling terpadu terbukti secara efektif menangani masalah-masalah seperti kecemasan, depresi, kecanduan alkohol, sikap tidak asertif, dan mampu meningkatkan kemampuan coping pada anak penderita ADHD. Proses konseling yang baik adalah sebuah proses konseling yang tidak mengabaikan unsur budaya konseli di dalamnya. Ketidaksesuaian budaya adalah salah satu permasalahan yang pada umumnya terjadi pada pendekatan-pendekatan konseling yang ada saat ini. Konseling terpadu muncul sebagai solusi untuk menjawab permasalahan tersebut. Konseling terpadu konselor dapat mengukur kebutuhankebutuhan khusus yang dibutuhkan oleh konseli berdasarkan latar belakang etnis dan budaya yang dibawanya ke dalam proses konseling. Konselor dihadapkan pada situasi dimana konselor harus mengembangkan fleksibilitas dalam menentukan arah strategi dalam konseling. Penggunaan perspektif terpadu membantu konselor bekerja dengan latar belakang sosial, budaya, spiritual, dan politik yang dimiliki oleh konseli, sehingga proses konseling dapat bermanfaat dan dapat membantu konseli keluar dari permasalahannya.

\section{DAFTAR PUSTAKA}

Arkowitz, H. (2002). Toward an Integrative Perspective on Resistance to Change. Psychotherapy in Practice, 58 (2), 219-227.

Corey, G. (2013). Theory \& Practice of Counseling \& Psychotherapy (8th Ed.). Belmont: Brooks/Cole.

Kenny, M.C. (2006). An Integrative Therapeutic Approach to the Treatment of a Depressed American Indian Client. Clinical Case Studies, $5(1), 37-52$.

Lampropoulos, G.K. \& Dixon, D.N. (2007). Psychotherapy Integration in Internships and Counseling Psychology Doctoral Programs. Journal of Psychotherapy Integration, 17(2), 185-208.

Portrie-Bethke, T.L., Hill, N.R., \& Bethke, J.G. (2009). Strength-Based Mental Health Counseling for Children with ADHD: An Integrative Model of 
Adventure-Based Counseling and Adlerian Play Therapy. Journal of Mental Health Counseling, 31 (4), 323-339.

Rijn, B., \& Wild, C. (2013). Humanistic and Integrative Therapies for Anxiety and Depression: PracticeBased Evaluation of Transactional Analysis, Gestalt, and Integrative Psychotherapies and PersonCentered Counseling. Transactional Analysis Journal, 43(2), 150-163.

Smith, M.L., \& Glass, G.V. (1977). MetaAnalysis Of Psychotherapy Outcome Studies. American Psychologist, 32(9), 752-760.

Sue, D.W., \& Sue, D. (2008). Counseling the Culturally Diverse (5th Ed.). New Jersey: John Wiley \& Sons.

The Institute of Integrative Psychotherapy. (2014). What is Integrative Psychotherapy?. Didownload 2014, 11 November, dari http:// www.integrativetherapy.com/en/ integrative-psychotherapy.php 